\author{
MILICA JAKÓBIEC-SEMKOWOWA \\ Uniwersytet Wrocławski \\ milica.semkow@gmail.com
}

\title{
Bałkański tygiel kultur i konfesji w dziewiętnastowiecznych relacjach polskich podróżników ${ }^{1}$
}

Podróżopisarstwo sięgające swymi początkami głębokiej starożytności należy do szczególnego działu piśmiennictwa stanowiącego przedmiot zainteresowania wielu dyscyplin naukowych. Badanie dawnych relacji z podróży - jak trafnie zauważa bibliolog Krzysztof Migoń — należy „, do historii (historii kultury, historii świadomości społecznej, historii idei), i do geografii (historii odkryć geograficznych i kształtowania się pojęć geograficznych), do historii literatury i do historii książki, i do innych jeszcze dyscyplin i kierunków badawczych"2. Przez wiele wieków opisy podróży realizowały przede wszystkim funkcję poznawczą; przewaga treści faktograficznych powodowała, że służyły one głównie jako źródło informacji. Stosunkowo wcześnie też zróżnicowały się ze względu na potencjalnego czytelnika, zaspokajając jego różne oczekiwania. Od XIX wieku w związku z żywiołowym rozwojem prasy zaistniała możliwość dotarcia do szerokich rzesz odbiorców, co z jednej strony dawało okazję do chwalebnych działań edukacyjnych, z drugiej zaś ograniczało zapędy autorów relacji do przedstawiania wysokospecjalistycznych badań i dociekań. Od połowy XVIII wieku, czyli od sentymentalizmu, zdecydowanie większy wpływ na kształt relacji od kategorii odbiorcy miała kategoria nadawcy — autora opisu. W szczególności wiązało się to z jego wykształceniem, nabytą wcześniej wiedzą na temat miejsc, do których

${ }^{1}$ Por. M. Jakóbiec-Semkowowa, Od misji do fascynacji. Relacje polskich jezuitów z bałkańskiego tygla kultur i Konfesji, [w:] XVII Musica Antiqua Europae Orientalis. Acta Slavica; Sacrum świata wschodniego i zachodniego w kulturze Słowiańszczyzny, red. A. Bezwiński, Bydgoszcz 2014, s. 155-170. Niniejsze opracowanie jest podbudowaną teoretycznie i istotnie wzbogaconą źródłowo wersją tego artykułu.

${ }^{2} \mathrm{~K}$. Migoń, Opis podróży jako typ książki i przedmiot lektury, „Czasopismo Zakładu Narodowego im. Ossolińskich", z. 10, 1999, s. 135-144, tu s. 135. 
zamierzał dotrzeć, a następnie konfrontacją oczekiwań, czyli najczęściej założonej z góry tezy — z rzeczywistością, z bezpośrednim doświadczeniem. Ostateczny kształt relacji zależał też oczywiście od osobowości autora i sprawności jego pióra.

Badanie polskich relacji z podróży po Bałkanach nie jest tematem nowym ani zapoznanym. Dzięki wydanym niedawno pod kierunkiem naukowym Krzysztofa Wrocławskiego bibliografiom, pieczołowicie zebranym i opatrzonym komentarzami, dotrzeć można bez trudu do relacji z podróży po Bośni ${ }^{3}$, Macedonii $^{4}$ i Czarnogórze ${ }^{5}$. Odnotować też należy wydany w Lublinie w 2010 roku obszerny tom zbiorowy Poludniowa Stowiańszczyzna w literaturze polskiej XIX i XX wieku pod redakcją Krzysztofa Stępnika i Moniki Gabryśb. Szczególną wartość ma otwierający ten tom przeglądowy artykuł Eugenii Prokop-Janiec Polskie podróże po Stowiańszczyźnie i dokumentowana licznymi przykładami zawarta w nim teza, że mieszczą się one w typie „podróży domowych”, wypraw relacjonowanych „z perspektywy kulturowej wspólnoty świata słowiańskiego"7. Specyfika „klucza narodowego”, która odcisnęła się w relacjach polskich podróżników, manifestujących często przynależność do wspólnoty Słowian, odróżnia je w znacznym stopniu od opisów wędrówek przedstawicieli świata zachodniego, ukazanych i zanalizowanych przez Božidara Jezernika ${ }^{8}$ i Marię Todorovą. Warto przytoczyć tu za nią ciętą charakterystykę tego typu pisarstwa autorstwa bułgarskiego uczonego z końca XIX wieku:

Osobliwe, że styl narracji często odzwierciedla cechy narodowe podróżników. Niemiec zapisuje przede wszystkim, co po drodze zjadł i wypił, gdzie wino było dobre, gdzie złe, gdzie towarzysze podróży zachorowali po zjedzeniu zbyt dużej ilości warzyw itp. Francuz - toujours galant - rzeźbi swoje imię na srebrnych monetach i obdziela tymi upominkami młode kobiety. Anglik, jak przystało na lojalnego syna Albionu i ucznia sentymentalnego Richardsona, nie omieszka zarejestrować w notesie cen towarów, ale jednocześnie wykazuje szczery zachwyt pięknem bałkańskiej przyrody ${ }^{9}$.

Niezależnie od poczucia bliskości i wykazywanych podobieństw — stwierdza Prokop-Janiec — południowa Słowiańszczyzna ukazywała się polskim wę-

${ }^{3}$ Polacy w Bośni. Polacy o Bośni. Przewodnik bibliograficzny z komentarzami, oprac. K. Wrocławski, M. Bogusławska, N. Różycki, Warszawa 2003.

${ }^{4}$ K. Wrocławski, M. Bogusławska, E. Wróblewska-Trochimiuk, Polska i Macedonia. Bibliografia. Komentarze. Studia, Warszawa 2009.

${ }^{5}$ Polska i Czarnogóra. Bibliografia. Komentarze, oprac. K. Wrocławski et al., Warszawa 2007.

${ }^{6}$ Poludniowa Stowiańszczyzna w literaturze polskiej XIX i XX wieku, red. K. Stępnik, M. Gabryś, Lublin 2010.

${ }^{7}$ E. Prokop-Janiec, Polskie podróże po Słowiańszczyźnie, [w:] Południowa Słowiańszczyzna..., s. 12.

${ }^{8}$ B. Jezernik, Dzika Europa. Bałkany w oczach zachodnich podróżników, przeł. P. Oczko, Kraków 2007.

${ }^{9}$ Ivan Šišmanov, 1891, Stari patuvanija prez Balgarija..., cyt. za: M. Todorova, Bałkany wyobrażone. [Imagining the Balkans], przeł. P. Szymor, M. Budzińska, Wołowiec 2008, s. 248. 
drowcom jako świat bardziej złożony, heterogeniczny i wieloaspektowy. Płaszczyzną, na której owa dyferencjacja szczególnie dawała o sobie znać, było zróżnicowanie konfesji.

Specyfika kulturowa słowiańskich Bałkanów, podzielonych od momentu przyjęcia chrześcijaństwa pomiędzy strefy wpływów Wschodu i Zachodu, pozwala obserwować zetknięcie różnych form doświadczania i przeżywania $S a$ crum jako stan permanentny. Istnienie obok siebie w bezpośrednim sąsiedztwie różnych wspólnot religijnych, nie tylko chrześcijańskich, posługujących się na co dzień na ogół tym samym językiem, nie budziło przez wieki demonów nienawiści, wszystkich bowiem łączyła obawa przed wspólnym wrogiem, Obcym, czyli przede wszystkim panującym na Bałkanach imperium osmańskim.

W drugiej połowie XIX wieku sytuacja bałkańskich Słowian istotnie się zmieniła. Kongres berliński, będący w rzeczywistości polem rozgrywki pomiędzy głównymi siłami politycznymi ówczesnej Europy, przy znikomym udziale przedstawicieli walczących o niepodległość Słowian bałkańskich, potwierdził w 1878 roku pełną niezależność Księstwa Serbskiego, które rychło przekształciło się w Królestwo (1882), a miejsce Turków w Bośni zajęła Austria, najpierw ją okupując, a następnie w 1908 roku wcielając w obręb monarchii Habsburgów. Kongres potwierdził też niezależność Czarnogóry, wyłączając jednakże z jej granic Zatokę Kotorską z ważnym ze strategicznego punktu widzenia portem w Kotorze, który był najdalej wysuniętym na południe przyczółkiem Austro-Węgier. W ten sposób nie uczestnicząc w działaniach wojennych na Bałkanach, „Austro-Węgry [...] otrzymały w prezencie od mocarstw rozległą prowincję, liczącą wówczas 1242458 ludności"10.

W wyniku decyzji politycznych przed Polakami żyjącymi w zaborze austriackim otworzyły się wrota Bałkanów, po których znacznej części mogli się odtąd swobodnie poruszać bez wiz i paszportów. Polityka dworu wiedeńskiego zmierzająca do ściślejszego zespolenia tych ziem z całym imperium spowodowała istotne zmiany w sferze gospodarczej i społecznej. Zacofana Bośnia i Hercegowina wymagały licznych inwestycji i modernizacji; od dróg i kolei żelaznej począwszy, do organizacji systemu oświaty i uporządkowania relacji pomiędzy wyznawcami wielu religii. Zacofane rolnictwo i opuszczone na skutek wojny bądź migracji gospodarstwa potrzebowały znaczącego dopływu rąk do pracy, podobnie jak przemysł i rozbudowana administracja austriacka. Do Bośni kierowani więc byli z różnych stron Austro-Węgier nie tylko inżynierowie, lekarze i urzędnicy, lecz także rodziny chłopskie ze Słowacji i Galicji, którym obiecywano radykalną poprawę bytu w stosunku do przysłowiowej nędzy galicyjskiej. Niezależnie od prowadzonej przez Wiedeń polityki germanizacyjnej, która pozostawała $\mathrm{w}$ narastającym konflikcie $\mathrm{z}$ aspiracjami niepodległościowymi tego regionu, dokonujące się na przełomie XIX i XX wieku przemiany cywilizacyjne miały walor pozytywny - przywracały Bośnię Europie. Skutkowało to również

10 W. Felczak, T. Wasilewski, Historia Jugosławii, Wrocław 1985, s. 367. 
ożywieniem kontaktów polsko-bośniackich, choć miały one charakter zdecydowanie jednokierunkowy: na Bałkany przybywali liczni Polacy, istotnie zasilając rodzącą się klasę inteligencji, jak również chłopi galicyjscy. Wart odnotowania jest jeden znamienny przypadek odwrotnego kierunku kontaktów: urodzony w Bośni Ivo Andrić przyjechał do Krakowa na studia na Uniwersytecie Jagiellońskim.

Polacy, reprezentanci różnych zawodów, odegrali znaczącą rolę w procesie przemian, chętnie też dzielili się swymi obserwacjami z pobytu w Bośni, zamieszczając $\mathrm{w}$ prasie polskiej różnego typu materiały, które skrzętnie gromadzi wspomniana bibliografia.

Podróżujący po austriackiej Bośni Polacy niejednokrotnie też korzystali z okazji dotarcia do Czarnogóry, której atrakcyjność datuje się jeszcze z minionej epoki, kiedy to uformował się romantyczny wizerunek tego niezwykłego zakątka Bałkanów. Relacje z tych wypraw omawia częściowo Magdalena Bogusławska, konfrontując ów wizerunek ze zmitologizowanym stereotypem tej krainy ukształtowanym w wykładach paryskich Adama Mickiewicza ${ }^{11}$. Do ciekawych ustaleń autorki warto by dodać analizę obszernych opisów podróży autorstwa Romana Zmorskiego, który dał się poznać także jako znawca i zasłużony tłumacz ludowej poezji serbskiej na język polski.

Czyniąc główną osią przeglądu opisów podróży obserwacje dotyczące różnych konfesji, w pierwszej kolejności należy zwrócić uwagę na zróżnicowany świat chrześcijański. Przedmiotem bliższej analizy będą relacje misjonarzy, etnografów i historyków, których wykształcenie i wiedza gwarantują w miarę obiektywny obraz bałkańskiego tygla kultur i wyznań. Korzystnie odróżnia je to od obserwacji autorstwa łowców różnego typu osobliwości odbiegających od zachodnioeuropejskich norm i obyczajów. Tego typu relacje obficie cytuje B. Jezernik i M. Todorova. Spostrzeżenia polskich autorów pozwalają więc na przybliżenie problemów, których reperkusje sięgają niemal do naszych czasów.

Autorzy interesujących nas opisów podróży to księża jezuici: Marcin Czermiński (1860-1931) i Jan Badeni (1858-1899), obaj pochodzący z Galicji, starannie wykształceni, odbywający liczne podróże po Europie i Azji Mniejszej, oraz trzeci duchowny, urodzony w Rzeszowie, Julian Antoni Łukaszkiewicz (1857-1937). Świeckim piórem zaś spisał swe bogate doświadczenia bałkańskie Aleksander Jabłonowski (1829-1912), zasłużony historyk i etnolog, który zainteresowanie Słowiańszczyzną Południową zawdzięczał studiom slawistycznym na Uniwersytecie Kijowskim, gdzie zaprzyjaźnił się z młodzieżą przybyłą z Bałkanów i skąd wyniósł, jak zapisał to w spisanej pod koniec życia Autobiografii, „niepokonaną

${ }^{11}$ M. Bogusławska, Wyprawy do źródet czasu. Obraz Czarnogóry w polskich relacjach podróżniczych z XIX wieku, [w:] 110 година полонистике у Србији. Зборник радова, Београд 2006, s. 277-285. Zabrakło w tym omówieniu ważnej postaci Romana Zmorskiego, autora nie tylko obszernych opisów podróży, lecz także licznych i wartościowych przekładów folkloru serbskiego na język polski. Por. M. Jakóbiec-Semkowowa, Roman Zmorski jako znawca i tlumacz ludowej poezji serbskiej, „Prace Literackie” VII, Wrocław 1965, s. 61-97. 
predylekcję do świata południowosłowiańskiego"12. Ten zapoznany nieco przez slawistów uczony samodzielnie pogłębiał wiedzę na temat Słowian na wielu europejskich uniwersytetach, między innymi w Dorpacie i na Sorbonie, w Londynie zajął się na przykład problemem etnogenezy. Pierwszą wyprawę na Bałkany odbył w latach 1859-1861, po drodze zatrzymał się w Wiedniu, gdzie słuchał wykładów Franja Miklošicia i odwiedził Vuka Karadžicia. Następnie podróżował po Bałkanach w latach siedemdziesiątych, zamieszczając relacje w czasopismach francuskich oraz polskich, zebrane następnie w pięciotomowej edycji pism, wydanej tuż przed śmiercią w 1912 roku. Znalazło się tam ponad dwadzieścia tekstów dotyczących Bałkanów: zarówno poważnych rozpraw naukowych, jak i relacji z podróży odbywanych w latach sześćdziesiątych i siedemdziesiątych XIX wieku ${ }^{13}$.

Ze względu na postawiony w tytule problem współistnienia na Bałkanach różnych konfesji warto przyjrzeć się w pierwszej kolejności autorom szczególnie na te problemy wyczulonym — księżom jezuitom.

Ksiądz Marcin Czermiński podróżował po Bałkanach wielokrotnie w latach 1892-1909. O tych wyprawach do Bośni i Hercegowiny pisała Magdalena Bogusławska ${ }^{14}$. Jego relacje drukowane najpierw w jezuickim miesięczniku „Misje Katolickie" zebrane zostały w dwu książkach: W Dalmacji i Czarnogórze (1896) i Z podróży po Bośni i Hercegowinie (1899). Na stronie tytułowej drugiej z nich znajduje się ilustracja przedstawiająca jeden z sarajewskich meczetów z wysmukłą wieżyczką minaretu; już w ten sposób autor sygnalizuje zarówno egzotykę, jak i swoje zainteresowanie specyfiką kulturową tego rejonu. Podróże Czermińskiego miały przede wszystkim charakter misyjny, niósł on posługę religijną do rozsianych po Bośni kolonii polskich przesiedleńców. Opisywał więc przede wszystkim wydarzenia o charakterze misyjnym: sprawowane w różnych, często bardzo skromnych warunkach msze święte, inne uroczystości religijne (postawienie krzyża, poświęcenie cmentarza, procesja w Niedzielę Palmową), rekolekcje i skrzętnie policzone setki spowiedzi. Jest to poruszające świadectwo sługi Bożego niosącego pociechę duchową rodakom, jak też grekokatolikom, Rusinom. Problemy katolików — polskich osadników w Bośni — rozpatruje Czermiński w pierwszym rozdziale wspomnianej obszernej książki na szerokim tle historycznym, relacjonując pokrótce dzieje tej krainy na podstawie źródeł encyklopedycznych oraz opracowań naukowych. Już na wstępie zaznacza, że od $\mathrm{X}$ wieku ścierają się tu wpływy religijne Wschodu i Zachodu, a pod koniec XIX liczba katolików wynosi 333306 wyznawców wobec dwukrotnie większej liczby wyznawców kościoła wschodniego (667 861), znacznej liczby muzułmanów

12 A. Jabłonowski, Autobiografia, Lwów 1939, s. 11.

13 A. Jabłonowski, Stowiańszczyzna południowa oraz Wołosza i Albania, [w:] Pisma Aleksandra Jabłonowskiego, t. 5, Warszawa 1911.

${ }^{14}$ Por. M. Bogusławska, Obraz stosunków międzywyznaniowych w Bośni i Hercegowinie końca XIX wieku w zapisach z podróży ks. Marcina Czermińskiego, „Pamiętnik Słowiański” LV, 2005, s. 59-76. 
(548 818), 8208 Żydów i około 4000 wyznawców innych religii1 ${ }^{15}$. Podziały religijne niezupełnie nakładają się na podziały narodowościowe:

Katolik nazywa się Bośniakiem lub Chorwatem, wschodniego wyznania Serbem, Muzułmanin zaś nazywa się czasem Bośniakiem, nigdy Serbem, lecz najczęściej Muzułmaninem, jak Żydzi tamtejsi Spaniolami — ponieważ rzeczywiście z Hiszpanii pochodzą [...]. Zresztą wszyscy, tak Chrześcijanie jak Muzułmanie używają wyłącznie kroacko-serbskiego języka, nie różniącego się prawie w niczem od mowy Dalmatyńców, Czarnogórców lub Serbów ${ }^{16}$.

Polscy chłopi-osadnicy w Bośni prócz kłopotów ze zbiurokratyzowanym austriackim aparatem urzędniczym mają poważny problem z ,opieką duchową”: „jedni emigranci dziczeją - inni tracą wiarę"17. Nie lepiej przedstawia się sytuacja $\mathrm{w}$ środowisku inteligenckim $(70 \%$ aparatu sądowniczego stanowią Polacy - podaje Czermiński), głównie ze względu na problemy językowe, a także nieobecność na tym terenie bośniackiej inteligencji katolickiej, co skutkuje brakiem kontaktów towarzyskich, choć wszyscy są gościnni. „Z Serbami życie ma być trudne i niemiłe dla ich podejrzliwości i fałszywego charakteru; już łatwiej z muzułmanami, u których ogłada towarzyska nie jest rzadkością, a przy tem są otwarci"18. Historycznym wywodem argumentuje również autor odmienność sytuacji w Hercegowinie, gdzie ludność katolicka, klasa „biedniejsza ale silniejszej wiary" oparła się apostazji i wyczekiwała kresu panowania osmańskiego przy znacznym wsparciu franciszkanów, szlachta natomiast w trosce o zachowanie przywilejów $\mathrm{w}$ większości przyjęła islam.

W tym miejscu warto przywołać także interesujące spostrzeżenia Aleksandra Jabłonowskiego, który wcześniej jeszcze (1872), a więc w czasach tureckich, podróżując po Hercegowinie, dostrzega wyraźne społeczne zróżnicowanie konfesji (biedna „raja” to chrześcijanie, katolicy) i obszernie tłumaczy historyczne uwarunkowania tego stanu rzeczy ${ }^{19}$.

Gdy w 1881 roku ustanowiona została na tych ziemiach nowa hierarchia kościoła katolickiego, a w 1891 biskupstwo stołeczne w Sarajewie zostało podniesione do rangi metropolii, ,wszystko należało od podstaw budować" ${ }^{20}$. Dostrzegając znaczny wzrost instytucji kościelnych w czasach rządów austriackich, Czermiński uważa, że katolicy są gorzej (,po macoszemu”) traktowani od Muzułmanów i Serbów, a nawet od protestantów i Żydów.

Odrębnym problemem misyjnym, z którym zetknął się ks. Czermiński w Bośni i Hercegowinie, była sytuacja przesiedlonych tam galicyjskich Rusinów, grekokatolików. Nie znajdując na nowym miejscu współwyznawców, niektórzy

15 M. Czermiński, Z podróży po Bośni i Hercegowinie, Kraków 1899, s. 5. Współcześni autorzy podają dane z 1895 r.: prawosławni - 43\%, muzułmanie - $23 \%$, katolicy $21 \%$. Por. W. Felczak, T. Wasilewski, op. cit., s. 377.

${ }^{16}$ M. Czermiński, Z podróży po Bośni..., s. 5.

17 Ibidem, s. 36.

18 Ibidem, s. 39-40.

19 A. Jabłonowski, Hercegowina, [w:] Pisma ..., t. 5, s. 45-93.

20 M. Czermiński, Z podróży po Bośni..., s. 150. 
zwracali się ku prawosławiu zachęceni językiem liturgii słowiańskiej oraz takim samym jak w kraju ich pochodzenia kalendarzem świąt. Miejscowi popi przekonywali ich również twierdzeniem, że „serbska wiara” i kalendarz juliański są starsze i „prawdziwsze”. W dyskusji z przedstawicielami tej grupy pojawia się jeszcze jeden istotny argument: galicyjscy Rusini kojarzą katolicyzm przede wszystkim z polskością, a swojego poczucia narodowego nie chcą się wyrzec: „Myśmy byli Rusinami i Rusinami zostaniemy, nie damy się spolszczyć!”21. Posługujący się swobodnie ich językiem Czermiński gorliwie i skutecznie wypełnia zadanie misyjne ${ }^{22}$.

Specyficzny charakter podróży ks. Czermińskiego po Bośni i Hercegowinie sprawia, że środowisko katolickie reprezentują w jego relacji niemal wyłącznie Polacy i marginalnie greckokatoliccy Rusini. Z nielicznymi śladami tradycji katolickiej zetknął się ks. Czermiński podczas wcześniejszej podróży po Czarnogórze. Należący do Austrii Kotor nazywa „ostatnim szańcem katolicyzmu”, dla którego zagrożeniem są nie tylko Turcy i muzułmanie z sąsiedniej Albanii i Bośni, lecz także Czarnogórcy „,również innej wiary — szyzmatyckiej — więc może groźniejszej od samej Turcji”"23. Niedole nielicznych katolików i brak świątyni w stolicy Czarnogóry wiąże autor z przemożnym wpływem Rosji, której minister pełnomocny zajmuje uprzywilejowaną pozycję na dworze panującego księcia.

Odmienny obraz katolicyzmu na Bałkanach pojawia się u drugiego autora, ks. Jana Badeniego, którego trasa wędrówki na początku lat dziewięćdziesiątych XIX wieku wiodła bardziej utartymi szlakami i prowadziła od Lublany do Zagrzebia, a stamtąd do Belgradu. Druga wyprawa, początkowo morska, zaczęła się w Trieście i wzdłuż wybrzeża dalmatyńskiego skierowała go ku Czarnogórze. Relacje z podróży zamieszczane w wydawanym przez krakowskich jezuitów „Przeglądzie Powszechnym” zebrane zostały w dwu tomach zatytułowanych Między Stowianami wydanych w Krakowie w 1893 i 1896 roku $^{24}$. Opublikowana ostatnio monografia Andrzeja Pawła Biesia ${ }^{25}$ przybliża tę interesującą postać. Zanim wyruszył na Bałkany, Badeni — absolwent studiów teologicznych w Kra-

${ }^{21}$ Ibidem, s. 333.

22 O skuteczności tych działań przekonał się Czermiński podczas kolejnych misji sprawowanych wiosną 1900 r. Starosta Prnjavoru nie tylko chwali Rusinów za gospodarność, ale też oświadcza, a miejscowy proboszcz to potwierdza, że „wszyscy bez wyjątku uczęszczają do katolickiego kościoła", a sam autor przekonuje się o tym po kilku dniach, gdy do sakramentów przystępuje kilkaset osób. „Mogłoby się zdawać, że to nie Bośnia, lecz jakieś wschodnio-galicyjskie miasteczko” (artykuł z „Misji katolickich” 1900, s. 170, przedrukowany współcześnie w osobnej współczesnej broszurce bez podania miejsca i roku wydania: M. Czermiński, Missya w Bośni od dnia 22 marca do 2 maja 190, s. 5).

${ }^{23}$ M. Czermiński, W Dalmacji i Czarnogórze, Kraków 1896, s. 255.

24 J. Badeni, Między Stowianami, z. I, Kraków 1893 [tu: W Zagrzebiu i Nad serbskim Dunajem], z. II, Kraków 1896 [tu: Dalmackim brzegiem i W czarnogórskiej stolicy]. Badeni opisał też swoje pobyty w Słowenii, na Słowacczyźnie, na Morawach, Łużycach i wśród Hucułów.

${ }^{25}$ A.P. Bieś, Jan Badeni SJ. U początków ruchu społecznego katolików w Galicji, Kraków 2012. 
kowie, uzupełnionych w Wiedniu - opanował na tyle kilka języków słowiańskich, że swobodnie się nimi posługiwał. Dzięki pracy w redakcji „Przeglądu Powszechnego" zyskał solidne oczytanie w prasie zagranicznej, doskonalił też swój warsztat dziennikarski, co szczególnie uwidoczniło się, zdaniem Biesia, w opisach podróży po Bałkanach. Autor monografii uważa te relacje za nadal cenne źródło informacji, ,pouczający opis, dokumentujący społeczną codzienność w wielokulturowej monarchii habsburskiej, odznaczający się rzetelnością przekazu wynikającą ze wzniesienia się ponad osobiste uprzedzenia" 26 .

Spostrzeżenia Badeniego dotyczące zdecydowanie katolickiej Chorwacji i wybrzeża dalmatyńskiego — oprócz szkicowych obserwacji przyrody, miast i zabytków - obfitują w rozważania natury historycznej, a w jeszcze większym stopniu — politycznej; do tradycyjnego konfliktu interesów Austrii i Węgier w Chorwacji i jej nadmorskiej części — Dalmacji dochodzą tu bowiem resentymenty włoskie. Przynależność konfesyjna ludności nie budzi wątpliwości, więc Badeni zaraz na wstępie wyraża przekonanie, że Zagrzeb jest stolicą nie tylko Chorwacji, lecz także „,ałej południowej, zwłaszcza katolickiej Słowiańszczyzny"27. Autor jednak zdaje sobie sprawę z obecności na wybrzeżu również prawosławnych Serbów (,żywioł serbski, mówiąc inaczej, prawosławny w Dalmacji rośnie i wzmaga się"), świadomych swej odrębności, zwłaszcza religijnej, „zapatrzonych na samodzielnie rozwijające się bratnie serbskie królestwo [... i] czarnogórskie gniazdo"28. Podziela przy tym ubolewania duchowieństwa katolickiego, iż rząd wiedeński „przez długie lata otaczał prawosławie i prawosławnych szczególną opieką, wyjątkowemi pieszczotami; nie szczędził ni grosza, ni przywilejów, dlatego prawdopodobnie, aby grymaszących przekonać, że nigdzie im tak dobrze nie będzie, jak w Austrii"29.

Zupełnie inaczej wygląda sytuacja katolików w prawosławnej Serbii i Czarnogórze. W czasie kilkudniowego pobytu w stolicy nad Dunajem Badeni bezskutecznie wypytuje o kościół, nie udaje mu się też spotkać żadnego katolika, aż w końcu dowiaduje się o istnieniu skromnej kapliczki w ogrodzie ambasadora austriackiego. Uznaje to za poważny błąd władz austriackich, które ,powinny postarać się” o kościółek i paru misjonarzy, którzy „najzrozumialszym dla tłumów językiem [głosiliby] potęgę, bogactwo, sławę sąsiedniego, katolickiego mocarstwa" $^{30}$. Autor wyraźnie myli misję religijną z polityczną.

Zwiedzając stolicę Czarnogóry Badeni kieruje podobny wyrzut pod adresem władz austriackich, które zamiast pomagać katolikom, przysyłają do Cetyni prawosławnego konsula, o czym także pisał Czermiński ${ }^{31}$. W tej sytuacji nie pomaga nawet wsparcie poważnych autorytetów, takich jak chorwacki biskup,

\footnotetext{
${ }^{26}$ A.P. Bieś, op. cit., s. 163.

27 J. Badeni, W Zagrzebiu..., z. I, s. 42.

28 J. Badeni, Dalmackim brzegiem, z. II, s. 93.

29 Ibidem.

30 J. Badeni, Nad serbskim Dunajem, z. I, s. 91.

31 Por. M. Czermiński, W Dalmacji..., s. 277.
} 
polityk i mecenas sztuki Josip Juraj Strossmayer. Katolicy spotykają się z rzadka w zaimprowizowanej kapliczce w prywatnym warsztacie szewskim, wówczas tylko gdy zjawi się jakiś przyjezdny duchowny. Autorowi sprawującemu tam mszę świętą przypomina to stajenkę Betlejemską. Brak opieki duchowej powoduje, że katolicy w potrzebie zwracają się do prawosławnego popa, który chrzci i odprawia pogrzeby.

Podróże po Bośni i Hercegowinie pozwoliły też polskim wędrowcom i duchownym poznać bliżej najliczniejszych na tym terenie wyznawców prawosławia oraz zabytki inspirowanej przez niego kultury. W chronologicznie najwcześniejszej relacji autorstwa Aleksandra Jabłonowskiego znajdujemy interesujące dane liczbowe z początku lat siedemdziesiątych XIX wieku. W Mostarze, stolicy Hercegowiny, ,wyznawców kościoła wschodniego” jest 3500 na 500 katolików ${ }^{32}$. Z goryczą odnotowuje autor, iż „wobec przemożnej siły poturczeńców” nieliczni chrześcijanie „grecy i łacinnicy, po dawnemu własnym antagonizmem się obezwładniają" 33 .

Ksiądz Marcin Czermiński w swej pierwszej książce podróżopisarskiej określa prawosławie najczęściej terminem „szyzma”, w drugiej używa wyłącznie neutralnej nazwy „kościół wschodni”, podobnie jak Badeni, u którego „panująca szyzma" pojawiła się tylko jeden raz. Polscy jezuici nie podejmują w swych relacjach rozważań natury dogmatycznej; w relacjach z kontaktów z prawosławiem przeważa ton krytyczny dotyczący przede wszystkim niskiego poziomu prowincjonalnego duchowieństwa. Czermiński spotyka się też z przedstawicielami hierarchii. W Sarajewie przyjaźnie rozmawia $\mathrm{z}$ archimandrytą, który rad by „przyjąć Unię z Rzymem”34, ale uniemożliwiają to względy natury politycznej. Równie korzystne wrażenie odnosi z wizyty w Mostarze u metropolity Perovicia, wyraźnie ucieszonego tym spotkaniem.

Proces wtapiania się niższego duchowieństwa prawosławnego w środowisko wiejskie tłumaczy ksiądz Badeni względami historycznymi, czyli głównie wielowiekową niewolą turecką. „Pasterz duchowy [...] wespół z nim [z chłopem] w polu pracował, nieraz z głodu przymierał i szedł po żebraczym chlebie"35. Wspólna niedola powodowała też niemal zupełny zanik dystansu pomiędzy osobami duchownymi a prostym ludem. Pisze o tym także Marcin Czermiński, zwracając uwagę na zaniedbywanie przez bośniackich popów praktyk religijnych, lekceważące traktowanie spowiedzi ${ }^{36}$. Chętnie uczestniczą oni natomiast $\mathrm{w}$ wiejskich zabawach przy muzyce i rakii.

32 A. Jabłonowski, Z nad Neretwy, [w:] Pisma..., t. 5, s. 128.

33 Ibidem, s. 129.

34 M. Czermiński, Z podróży po Bośni..., s. 158.

35 J. Badeni, Nad serbskim Dunajem, z. I, s. 86.

36 Taka sytuacja utrzymywała się na głębokiej prowincji bałkańskiej jeszcze przez całe dziesięciolecia. Podróżujący po południowej Serbii i Macedonii w 1936 r. późniejszy profesor slawista, Marian Jakóbiec, opisuje nocleg w domu popa w Globočicy. Staruszek 82-letni powszechnie poważany, wnuk bohatera walk z Turkami to „Żaden duchowny! Nie modli się, jest prostym, zwy- 
Drugim, po wielowiekowej niewoli tureckiej, ważnym powodem pauperyzacji i swego rodzaju schłopienia niższego duchowieństwa prawosławnego był brak wykształcenia zdecydowanie negatywnie oceniany przez obu polskich jezuitów. Jak pisze Marcin Czermiński, „do ostatnich czasów stało [ono] na bardzo niskim poziomie. Polegało głównie na wyuczeniu się liturgii na pamięć. Słyszałem od osób wiarygodnych, że nie wszyscy duchowni serbscy dawniejszej daty umieją czytać, a wiem na pewno, że nie wszyscy umieją pisać"37. Sytuacja w Bośni ma ulec radykalnej poprawie dzięki władzom austriackim, które subwencjonują budowę cerkwi, wypłacają zapomogi dla popów i budują w Sarajewie duży kompleks o charakterze oświatowym. Z tych też funduszy powstało w Hreljevie prawosławne seminarium duchowne. Wrażenia wyniesione ze zwiedzania tego opisanego szczegółowo obiektu nie dają jednak podstaw do optymizmu; więcej niż skromna biblioteka, świeccy nauczyciele i sposób kształcenia, zdaniem Czermińskiego, nie zapewniają pogłębienia religijności, „wyrobienia ducha kapłańskiego"38, a skutkuje to narastaniem nienawiści do wszystkiego, co katolickie. Drastycznym przykładem jest formuła chrztu, w której do „wyrzeczenia się ducha złego” prowincjonalni popi dodają niekiedy zdanie o wyrzeczeniu się ,papieża rzymskiego”, czemu towarzyszy pogardliwe splunięcie.

Ksiądz Jan Badeni ilustruje natomiast zacofanie duchownych prawosławnych przytoczeniem obszernego, ponaddwuipółstronicowego tekstu relacji z wizytacji, jaką odbył gdzieś na serbskiej prowincji egzarcha belgradzki ${ }^{39}$. Cała seria pytań i odpowiedzi dowodzi przerażającej ignorancji i niewiedzy jakiegoś popa Piotra, tyle że tekst ten pochodzi sprzed ponad stupięćdziesięciu lat (z 1733 roku), a więc odnosi się do zupełnie innej rzeczywistości — czasów niewoli tureckiej. Polski autor znakomicie orientujący się $\mathrm{w}$ historii poskąpił tu niestety komentarza. Nie omieszkał jednak dodać, że ci nieoświeceni popi potrafili w czasie walk o niepodległość dokonywać cudów męstwa i odwagi, szkoda, że nie w życiu religijnym. Nadzieję na zmianę sytuacji wiąże z wprowadzonym przez parlament wolnej Serbii „przymusem szkolnym”, informuje też o zreformowanym systemie kształcenia kandydatów do stanu duchownego. Wyraźnie dostrzega Badeni otwarcie na Zachód, zwłaszcza kształconej tam inteligencji, ale jednocześnie także wpływy rosyjskie, które z polskiej perspektywy ocenia bardzo surowo. „Mniej oświecone masy, [...] zapatrzyły się w nęcącą ku sobie wspólnością religii, podobieństwem języka, wschodnia przepaść [podkr. MJS], i na oślep w nią się rzucić gotowe" 40 .

czajnym chłopem. Uczył się w Ohrydzie i to zamyka jego świat. [...] Świat obecny nie obchodzi go w ogóle, o Jugosławii nie wie prawie nic". M. Jakóbiec, Z daleka i z bliska. Wspomnienia i pamiętniki zebrane i uporządkowane przez córkę Milicę Jakóbiec-Semkowową, Wrocław 2009, s. 111.

${ }^{37}$ M. Czermiński, Z podróży po Bośni..., s. 160.

38 Ibidem, s. 162.

39 J. Badeni, Nad serbskim Dunajem, z. I, s. 87-89.

${ }^{40}$ Ibidem, s. 90. 
Niechętny stosunek Badeniego do serbskiego prawosławia przejawia się też w lekceważącym opisie belgradzkich cerkwi („Białogród ilością cerkwi bynajmniej nie grzeszy; kilka istniejących nie grzeszy ani pięknością, ani wielkością; a wierni znowu wcale do nich tak się nie cisną, aby była jakabądź racja budowania nowych" ${ }^{41}$ ) oraz nabożeństwa żałobnego, w którym przez chwilę uczestniczy. Nie najlepsze wrażenia, choć bez jakichkolwiek ocen wartościujących, wynosi też Czermiński z cerkwi przy monasterze Dobricievo, odnotowując stare, wyblakłe freski, zniszczone i pozbawione kart tytułowych księgi liturgiczne, brak tabernakulum i wiecznej lampki. Wnętrze natomiast sarajewskiej cerkwi metropolitalnej, a zwłaszcza bogate carskie wrota budzą jego autentyczny podziw, podobnie jak zachowane tam słowiańskie napisy.

Najwięcej zrozumiałej ciekawości budził w polskich podróżnikach po Bośni i Hercegowinie świat muzułmański. Bezpośredniego kontaktu z nim nie miał Jan Badeni, który podróżował innymi szlakami, odnotowując tylko w relacji z Belgradu nieliczne ślady długiej obecności Turków: opuszczony, zaniedbany meczet i funkcjonująca jeszcze łaźnia. Pisząc zaś o ludowej religijności, w której dostrzega elementy dawnych wierzeń pogańskich, zauważa też, że niektóre z obrzędów „od Turków w niemałej części zapożyczone” ${ }^{2}$. O Turkach — odwiecznych wrogach - jest też mowa w krótkim, kilkuzdaniowym zarysie historii Czarnogóry. Wspomniana jest „rzeź muzułmanów” z 1702 roku oraz liczne boje „z niewiernym Turczynem” opiewane w czarnogórskich pieśniach epickich, których żywotność go fascynuje.

Marcin Czermiński podejmuje charakterystykę świata muzułmańskiego w Bośni i Hercegowinie z pełną świadomością, że są to sprawy dla polskiego czytelnika zupełnie nieznane i obce, a dla opisu środowiska, w którym znaleźli się przesiedleńcy z Polski — niezbędne. Obraz islamu wyłaniający się z jego relacji został szczegółowo omówiony przez orientalistę Marka Dziekana ${ }^{43}$, który na wstępie określa podejście Czermińskiego do muzułmanów jako „przyjazny dystans”. „Niewiele znajdziemy u niego wypowiedzi dyskredytujących islam, a jeśli są, to bardzo wyważone - można powiedzieć dzisiejszym językiem, że ks. Czermiński jest bardzo »poprawny politycznie«"44.

Bliższa charakterystyka stosunków religijnych, interesująca kapłana jezuitę, ma także, w jego przekonaniu, ważny kontekst polityczny, w którym odbijają się posunięcia władz austriackich. Kilkakrotnie pojawiają się w tekście informacje o wsparciu finansowym udzielanym na budowę obiektów sakralnych. Spotkany na pograniczu hercegowińsko-czarnogórskim mieszkający tam Czech-katolik

${ }^{41}$ Ibidem, s. 83.

42 Ibidem, s. 84.

${ }^{43}$ M. Dziekan, Islam na Bałkanach w relacjach z podróży po Bośni i Hercegowinie ks. Marcina Czermińskiego SJ (1860-1931), „Południowosłowiańskie Zeszyty Naukowe. Język — Literatura - Kultura” 8, Łódź 2001, s. 133-163.

${ }^{4}$ Ibidem, s. 136. 
żali się, że za państwowe pieniądze został wzniesiony meczet i cerkiew, a brak choćby skromnej katolickiej kaplicy ${ }^{45}$. W Sarajewie autor zwiedza okazały gmach muzułmańskiej uczelni religijinej, szeriatu, zbudowany przez władze austriackie. Zachwyt nad pieczołowicie odtworzonym w budowli stylem mauretańskim i jej wyposażeniem idzie w parze z krytyczną oceną spotkanej tam młodzieży (,trochę zastraszona mojemi odwiedzinami [...] wzrok miała mdły, trochę barani”) ${ }^{46}$. Podobne wrażenia notuje autor podczas zwiedzania niższej szkoły wyznaniowej, medresy, mieszczącej się w nowo postawionym budynku również w stylu mauretańskim. Tu również „miny [młodzieży] wydały [...] się bardzo zastraszone i hardogłupie. U Turka do dobrego tonu należy dumnie spoglądać na chrześcijanina i rzucać nań okiem pogardy" ${ }^{47}$. Izolowaniu bośniacko-hercegowińskiego środowiska muzułmanów od zewnętrznych wpływów tureckich służy, jak odnotowuje Czermiński, wsparcie finansowe udzielane hierarchom muzułmańskim. Widoczne w działaniach Wiednia starania o zachowanie równowagi pomiędzy wyznawcami różnych religii $\mathrm{w}$ jednym przypadku budzą zdecydowany protest autora. $\mathrm{Z}$ goryczą pisze kilkakrotnie o egzekwowanym w praktyce, surowym zakazie nawracania muzułmanów na katolicyzm, podczas gdy konwersja na islam jest dopuszczalna.

Wiele miejsca w relacjach polskiego jezuity — zgodnie z regułami podróżopisarstwa - zajmują opisy charakterystycznych budowli: meczetów w Sarajewie i Travniku, cmentarza i twierdzy sarajewskiej oraz dzielnicy tureckiej — čaršiji, która zachowała średniowieczny koloryt orientalny. Towarzyszą im opisy typowych sprzętów, a także bardzo dokładne omówienia ubiorów. Bogaty materiał etnograficzny zgromadzony przez Czermińskiego uzupełniają interesujące obserwacje dotyczące ludzi - wyznawców islamu. Oficjalna pogarda wobec chrześcijan przestaje być odczuwana w kontaktach codziennych; Czermiński doświadcza różnego typu uprzejmości, których się nie spodziewał.

Zainteresowany odrębnością kulturową bośniackich muzułmanów polski jezuita przygląda się też ich praktykom religijnym, opisuje codzienne modlitwy (szczegółowa relacja ze wsi Jezero), do których hodża lub mufti nawołuje z minaretu „melancholijnym głosem”, wspomina o ekstatycznym tańcu derwiszów. Artefakty i wydarzenia, w których sam uczestniczy, rozmowy z miejscową ludnością Czermiński relacjonuje bezstronnie, z pozycji zewnętrznego obserwatora, dbając o najdrobniejsze niekiedy realia, unikając ocen wartościujących. Nie ukrywa jednak swego negatywnego nastawienia do wszelkich przejawów zacofania, zabobonów i pogardy dla wiedzy. Przytacza na przykład list muzułmańskiego sędziego do angielskiego archeologa, który prosił go o pewne informacje natury historycznej. W pełnych uprzejmości słowach („Znakomity przyjacielu! Radości żyjących!.. O, mój baranku’48) kadi odmawia ich podania, gdyż jest głęboko

45 M. Czermiński, Z podróży po Bośni..., s. 288.

${ }^{46}$ Ibidem, s. 180-181.

47 Ibidem, s. 129.

48 Ibidem, s. 130. 
przekonany, iż świat należy pozostawić temu, który go stworzył, a wszelkie dociekania nad jego istotą są niepotrzebne, a nawet mogą być niebezpieczne. Przytaczając drastyczny przykład, konkluduje jednoznacznie: „gdzie muzułmanin postawił swą stopę, zaraz następował zastój w naukach i sztukach, a nawet, co zastał, niszczył niemiłosiernie, mniejsza o to, czy były biblioteki bogate, czy monumentalne budowle" 49 .

Wielokrotnie wspomina Czermiński o miejscowych zabobonach, komentując, że „religia nie zabezpiecza [muzułmanów] od jakiejś niewidzialnej szkodliwej potęgi, i żadnej rady ni pociechy w nieszczęściu lub przygodach nie daje" ${ }^{\text {. }}$. W innym miejscu zauważa, że ,godnem zastanowienia jest wiara muzułmanów w potęgę nadziemską Kościoła katolickiego" ${ }^{51}$. Ten zaskakujący wniosek nasuwa się polskiemu jezuicie podczas nabożeństwa w klasztorze Podmilacze (oryg. Podmilačje). Raz w roku, 24 czerwca, odbywają się tam egzorcyzmy, w których uczestniczą przedstawiciele wszystkich narodowości i wyznań, gdyż sprawujący je franciszkanie minoryci nie odmawiają nikomu pomocy. Tradycja ta zachowała się do naszych czasów ${ }^{52}$. Wśród znacznego grona uczestników autor dostrzega licznie zgromadzonych muzułmanów.

Muszą być w ich oczach te fakta bardzo nadzwyczajne, skoro odważają się nie tylko wejść do katolickiego kościoła, którym w zasadzie gardzą, ale nawet przyprowadzają doń swe żony lub córki, które nigdy, nawet między samymi muzułmanami, nie biorą udziału we wspólnych zebraniach, a tem mniej wolno im wejść w jakąkolwiek styczność z chrześcijanami ${ }^{53}$.

Szczegółowo też opisuje Czermiński święto Bożego Ciała w hercegowińskim Trebinju. W procesji bierze udział „tłum ludzi rozmaitych wyznań”, a w orkiestrze ,z zapałem” przygrywa muzułmanin ${ }^{54}$.

Proces powolnej liberalizacji kontaktów pomiędzy wyznawcami różnych religii, zauważa autor, jest wynikiem unifikacyjnej polityki prowadzonej przez Austrię. Dostrzega on jednak także przebiegający oddolnie wielokierunkowy proces przejmowania wzorów życia i zachowań. Sferą najbardziej podatną na zbliżenie jest ludowy światopogląd magiczno-religijny. Autor wzmiankuje na przykład o „ufności Serbów i Muzułmanów w działanie wody święconej”, po którą „udają się do katolickich kapłanów, aby jej użyć jako prezerwatywy od złego" 55 .

\section{Ibidem.}

${ }^{50}$ Ibidem, s. 128.

51 Ibidem, s. 80.

${ }^{52}$ Msza w intencji chorych „se slavi na dan sv. Ive (24. lipnja) i na kojoj uz katolike sudjeluju i pripadnici drugih vjera, što je još jedna posebnost ovog svetišta. Ovdje se svake godine, uoči i na sam Ivandan, slijevaju deseci tisuća hodočasnika. Svetište sv. Ive u Podmilačju bilo je i ostaje paradigma vjere bosanskih katolika. Ovdje su se događala i događaju čudesna djela Božje milosti i obraćenja, izmoljena hodočasničkim zavjetima, pokorom i molitvom”. (Podkr. MJS), http:// www.zupa-podmilacje.com/podmilacje-dvd/ (dostęp: 20.05.2014).

${ }^{53}$ M. Czermiński, Z podróży po Bośni..., s. 80.

${ }^{54}$ Ibidem, s. 306.

55 Ibidem, s. 326. 
Z wielowiekowego sąsiedztwa wynika też przejmowanie od muzułmanów przez chrześcijan sposobów urządzania wnętrz mieszkalnych. Naturalne wydaje się więc ,urządzenie mieszkania na sposób turecki” przez prawosławnego metropolitę Perovicia w Mostarze, a także „tenże zwyczaj w przyjęciu: o godz. 11 przed południem czarna kawa, limoniada i rakia" ${ }^{, 5}$. Interesujący przykład asymilacji duchownych katolickich w mieszanym wyznaniowo środowisku lokalnym przytacza Czermiński, relacjonując wizytę w wiosce Bučić, „gdzie proboszcz miejscowy O. Stjepan Mašić, Minoryta, wiedzie prawdziwie sielankowy żywot. Zastaliśmy go na wzgórzu siedzącego w cieniu drzewa na tapczanie z fajką na długim tureckim cybuchu, w fezie na głowie" ${ }^{\text {57 }}$. Podobnie zaskakująco na pierwszy rzut oka wyglądają zakonnicy franciszkanie, którzy w czasach tureckich, aby nie rzucać się w oczy przebierali się w stroje chłopskie, a te już dawno upodobniły się do muzułmańskich. Także pod koniec XIX wieku mnisi z przygranicznego monasteru Dobricievo noszą się na co dzień jak czarnogórscy górale; odróżniają ich tylko brody i długie wąsy ${ }^{58}$. „Orientalizacja stroju, zachowań, sposobu bycia — pisze M. Bogusławska — pozwalała unikać prześladowań za wiarę, ułatwiała kontakt z wiernymi" ${ }^{59}$. Nawyki te nie zmieniły się w czasach austriackich mimo zachodzących głębokich przemian obyczajowych.

Konserwatyzm muzułmanów sarajewskich ilustruje Czermiński problemem, z jakim spotkały się austriackie władze oświatowe organizujące od podstaw edukację dziewcząt; każda propozycja była przez muzułmanów oprotestowana. Zastanawiający komentarz Czermińskiego:

Niezawodnie wyszło to tylko na dobre dziatwie chrześcijańskiej, która została ocaloną od stykania się z muzułmankami, od najmłodszych lat oddychającemi zgniłą atmosferą zepsucia i prowadzącymi najswobodniejszą rozmowę o wszystkiem zarówno z matką i innemi mężatkami, jak z hodżą, swym nauczycielem ${ }^{60}$

jest odzwierciedleniem głębokich uprzedzeń, których autor na ogół unika. Chętniej relacjonuje przejawy zrozumienia i wzajemnego szacunku pomiędzy przedstawicielami odmiennych wyznań, zwłaszcza we wzajemnym respektowaniu świąt religijnych.

Szczególny obraz islamu w Hercegowinie zarysowuje Aleksander Jabłonowski. W stosunku do jego wschodniego, tureckiego oblicza ,świat to zupełnie odrębny, samoistny, oryginalny, zwarty w sobie"61. Narzucona przez zdobywców wiara nie pozbawiła Hercegowińczyków poczucia narodowości słowiańskiej, jako „najdroższą spuściznę po ojcach” traktują oni swój język i zamiłowanie do poezji ${ }^{62}$, nienaruszony pozostał „obyczaj domowy”, jednożeństwo: „kobieta

56 Ibidem, s. 262.

57 Ibidem, s. 142.

58 Ibidem, s. 294.

${ }^{59}$ M. Bogusławska, Obraz stosunków..., s. 67.

${ }^{60}$ M. Czermiński, Z podróży po Bośni..., s. 156.

61 A. Jabłonowski, Z nad Neretwy, [w:] Pisma..., t. 5, s. 133.

62 Ibidem, s. 135. 
słowiańska stając się muzułmanką, wcale się ujarzmić nie dała!”63 . „Kultura obca islamu, na pniu słowiańskim najpomyślniej zaszczepiona i kwiatem bujnym okryta - to zaiste przedmiot godny najgłębszego zastanowienia się"

Czwartą znaczącą w XIX wieku wspólnotą religijną na Bałkanach, a zwłaszcza w Bośni, byli Żydzi, których obecność i funkcjonowanie w imperium osmańskim, a następnie pod rządami Austro-Węgier doczekało się także polskich współczesnych opracowań ${ }^{65}$. Polakom przybywającym z Galicji od razu rzucała się w oczy odrębność Sefardyjczyków, nazywanych wówczas Spaniolami, nie tylko w stosunku do innych etnosów zamieszkujących ów region, ale też w stosunku do ukształtowanego na ziemiach polskich obrazu Żydów. Czermiński, a także Badeni wyjaśniają okoliczności historyczne, które spowodowały przybycie Sefardyjczyków w XVI wieku na Bałkany, dostrzegają również odmienność typu antropologicznego. „Typowo różnią się od naszych Żydów, cerę mają ciemniejszą a wyraz twarzy więcej szlachetny”, zauważa Czermiński66. Z sympatią dla tej wspólnoty dodaje: „Na pochwałę tutejszych Żydów można powiedzieć, że z wyjątkiem lichwy, nigdy nie trudnili się brudnemi sprawami, a życie rodzinne bardzo jest u nich rozwinięte i piękne"67. Opisując szczegółowo ich ubiory, zauważa wpływy tureckie: noszone przez mężczyzn fezy, a przez kobiety — szarawary. Ten szczegół etnograficzny odnotowuje też jeszcze jeden podróżujący po Bośni polski duchowny, Julian Antoni Łukaszkiewicz (1857-1937), który swą relację z podróży po Bałkanach opublikował w 1904 roku ${ }^{68}$. Autor nie kryje swych antysemickich uprzedzeń; wyrażają się w jednostronnym przedstawieniu historii Sefardyjczyków - o ich przybyciu na Bałkany pisze on, że „było to na rękę sprzyjającym im Turkom, dzięki czemu [...] mogli żyć bez pracy, z lichwy i szachrajstwa, co sprzyjało bogaceniu się" ${ }^{\circ 9}$ - jak też w opisie powierzchowności: „mężczyźni mają wyraz twarzy ponury, choć inteligentny, kobiety są brzydkie i nieprzyjemne"70.

63 Ibidem, s. 134.

64 Ibidem, s. 133.

65 M. Bogusławska, Obraz stosunków...; M. Jakóbiec-Semkowowa, Wielokulturowość i asymilacja. O sarajewskich Sefardytach wedtug powieści Gordany Kuić, [w:] Tradycje pogranicza i przestrzenie tradycji. Od komunizmu do postmodernizmu i postkolonializmu, red. B. Zieliński, Poznań 2008, s. 169-179; M. Jakóbiec-Semkowowa, Sarajevo's Sephardim and Ashkenazim in a Literary Mirror of Thair Own and Foreign Authors, [w] Ashkenazim and Sephardim: a European Perspektive, red. A. Kupny, I. Olszewska, Frankfurt am Main 2013, s. 41-56.

66 M. Czermński, Z podróży po Bośni..., s. 166.

67 Ibidem, s. 166-167.

68 J.A. Łukaszkiewicz, Nad wodami Adryatyku. Istria - Kroacja - Dalmacja - Czarnogóra - Hercegowina - Bośnia, Poznań 1904. Pochodzący z Rzeszowa duchowny do 1918 r. mieszkał w Wiedniu, gdzie zajmował się tamtejszą Polonią. Por. S. Poręba, Julian Antoni Eukaszkiewicz, [hasło w:] Polski słownik biograficzny, t. 18, s. 553-554.

69 J.A. Łukaszkiewicz, op. cit., s. 362.

70 Ibidem, s. 363. 
W błędnej opinii Łukaszkiewicza Sefardyjczycy stoją wyżej w hierarchii niż napływający z rozległych stron imperium Habsburgów Aszkenazyjczycy. Poważne wątpliwości budzi jego sąd, iż tych ostatnich „,ieszy [...] to, że mogą zarzucić wstrętną nazwę Żydów i zwać się także Spanjolami" 71 .

Drobne okruchy antysemityzmu odnaleźć można zarówno w poprawnych politycznie, zrównoważonych opisach Czermińskiego ${ }^{72}$, jak też u Badeniego ${ }^{73}$; na rzeczywistości bałkańskiej odciskają swe piętno galicyjskie stereotypy.

Istotnym problemem tej wspólnoty, do końca niemal XIX wieku hermetycznie zamkniętej, co sprzyjało zachowaniu tożsamości i odrębności kulturowej, było zderzenie z napływającymi z różnych stron cesarstwa Habsburgów Aszkenazyjczykami. Początkowy nieuchronny konflikt wygasał bardzo powoli, a wyizolowana dotąd miejscowa społeczność sefardyjska włączała się stopniowo w przyspieszony rozwój cywilizacyjny całej prowincji ${ }^{74}$.

Analizowane powyżej relacje z Bałkanów spełniają podstawowy warunek podróżopisarstwa - są zapisem uporządkowanego chronologicznie bezpośredniego doświadczenia polskich autorów, wykształconych i dobrze przygotowanych, także językowo. Opisy wędrówek po Bałkanach miały z założenia pełnić funkcję informacyjną, skierowane były do szerokiego grona odbiorców - czytelników czasopism. Kanwą tych opowieści jest przemieszczanie się z miejsca na miejsce różnymi środkami lokomocji, noclegi i popasy, rozmowy z przedstawicielami różnych narodowości, wyznań, stanów i profesji. Na tej „podróżnicznej” kanwie autorzy snują wiele wątków uzupełniających, niekiedy przybierających postać poważnych rozważań historycznych (Jabłonowski). Dostrzegają zróżnicowanie religijne zwiedzanych krain, skomplikowane dzieje chrześcijaństwa na Bałkanach, ale nie wchodząc w kwestie dogmatyczne, reagują zdecydowanie negatywnie na prymitywizm i zacofanie. Bogactwo opisów o charakterze entograficznym idzie w parze z obojętnością wobec zabytków sakralnych. Krytycyzm i upolitycznienie relacji (wyraźna sympatia dla działań Austrii) ustępują przed autentycznym zachwytem nad przyrodą i w obliczu poczucia wspólnoty, co przejawia się w umiłowaniu wolności.

${ }^{71}$ Ibidem.

72 Polscy aptekarze w Tuzli „niestety” okazują się Żydami, starosta w Stolaczu, pochodzący z Galicji, nie przyznaje się do znajomości języka polskiego: „czy może nosił na sobie piętno mniej sympatycznej rasy? Na pewno nie wiem, // lecz fizjonomia go zdradzała" (Z podróży po Bośni..., s. 280).

73 Więcej niż skromny zajazd w stolicy Czarnogóry okazuje się „na szczęście nie żydowski”, a czarnogórski karczmarz „nie w jupicy, nie w jarmułce”.

74 Por. M. Jakóbiec-Semkowowa, Sarajevo's Sephardim and Ashkenazim... 


\section{Balkan melting pot of cultures and denominations in light of the 19th-century works of Polish travellers}

Summary

Out of numerous available Polish trip descriptions written at the end of the 19th century we have chosen the works by three Jesuits, Marcin Czermiński, Jan Badeni, and Julian Antoni Łukaszewicz, and a historian and ethnologist Aleksander Jabłonowski. Those works were by no means accidental: all the authors were experts in the matter of specific Balkan culture. We particularly analyse the authors' interesting remarks on different denominations: Catholicism, Greek Orthodox Church, Islam and Judaism and relationships between members of these denominations. In their works the Polish authors frequently referred to the existing feeling of Slavic unity. At the same time they noticed the complexity of historical and political backgrounds which were then easily perceived in the region.

Keywords: trip descriptions, Catholicism, Greek Orthodox Church, Islam, Judaism, Slavic unity.

\section{Балкански конгломерат култура и вероисповести у пољским путописима друге половине 19. века}

Резиме

За анализу насловног проблема изабрани су из многих релација путописи пољских исусоваца Марћина Чермињског (Marcin Czermiński), Јана Баденија (Jan Badeni), Јулиана Антонија Лукашкјевича (Julian Antoni Łukaszkiewicz) и историчара и етнолога Александра Јаблоновског (Aleksander Jabłonowski). Сви аутори су били добро припремљени и добро су познавали специфику културе балканских Словена. Обраћали су пажњу на разне вероисповести: католицизам, православље, ислам и јудеизам а такође на односе међу њиховим припадницима. Пољски аутори често су се позивали на братство Словена и истовремено су подвлачили комплицирану историју овог региона и текуће политичке услове.

Кључне речи: пољски путописи, католицизам, православље, ислам, јудеизам, братство Словена. 